\title{
Ornithinimicrobium kibberense sp. nov., isolated from the Indian Himalayas
}

Correspondence
S. Mayilraj
mayil@imtech.res.in

Correspondence

mayil@imtech.res.in

\author{
S. Mayilraj, ${ }^{1}$ P. Saha, ${ }^{1}$ K. Suresh ${ }^{1}$ and H. S. Saini ${ }^{2}$ \\ ${ }^{1}$ Microbial Type Culture Collection and Gene Bank (MTCC), Institute of Microbial Technology, \\ Sector 39-A, Chandigarh, 160 036, India \\ ${ }^{2}$ Department of Microbiology, Guru Nanak Dev University (GNDU), Amritsar, 144 005, India
}

The suborder Micrococcineae Stackebrandt et al. 1997 currently consists of the following genera, which contain ornithine as diagnostic amino acid in their peptidoglycan: Cellulomonas Bergey et al. 1923, Curtobacterium Yamada and Komagata 1972, Rarobacter Yamamoto et al. 1988, Microbacterium Orla-Jensen 1919 emend. Takeuchi and Hatano 1998, Ornithinicoccus Groth et al. 1999, Salana von Wintzingerode et al. 2001, Ornithinimicrobium Groth et al. 2001, Rhodoglobus Sheridan et al. 2003, Arsenicicoccus Collins et al. 2004 and Serinicoccus Yi et al. 2004. At the time of writing, the genus Ornithinimicrobium consists of only one species, Ornithinimicrobium humiphilum. In this study, a novel strain is described, $\mathrm{K} 22-20^{\mathrm{T}}$, which was isolated from a soil sample collected from Lahaul-Spiti valley in the Indian Himalayas.

Strain $\mathrm{K} 22-20^{\mathrm{T}}$ was isolated by the dilution-plate technique on tryptone soya agar medium (TSA; HiMedia) and maintained as glycerol stocks at $-70{ }^{\circ} \mathrm{C}$. The reference strain Ornithinimicrobium humiphilum MTCC $6406^{\mathrm{T}}$ was taken from the Microbial Type Culture Collection and Gene Bank (MTCC), Chandigarh, India. Strain K22-20 ${ }^{\mathrm{T}}$ and O. humiphilum MTCC $6406^{\mathrm{T}}$ were grown on TSA at $28^{\circ} \mathrm{C}$ and morphological and physiological properties were analysed. Colony and cell morphology were studied according to standard methods (Murray et al., 1994). Gram reaction was

The GenBank/EMBL/DDBJ accession number for the 16S rRNA gene sequence of Ornithinimicrobium kibberense strain $\mathrm{K} 22-2 \mathrm{O}^{\top}$ is AY636111. determined using the HiMedia Gram Staining kit according to the manufacturer's instructions. Physiological tests such as growth at different temperatures, $\mathrm{pH}$ and $\mathrm{NaCl}$ concentrations were examined by growing the strain on basal TSA. Catalase and urea hydrolysis were determined as described by Cowan \& Steel (1965). Hydrolysis of casein, gelatin and starch, hydrogen sulphide production, methyl red and Voges-Proskauer tests and the presence of oxidase were determined as described by Smibert \& Krieg (1994). Nitrate reduction and indole production were determined as described by Claus \& Berkeley (1986). Utilization of various carbon sources was tested according to Reddy et al. (2003) and also using Biolog GP2 MicroPlates. The plates were used according to the manufacturer's instructions except that TSA medium was used instead of Biolog Universal Growth agar medium. Inoculated plates were incubated for $24 \mathrm{~h}$ and results were read with a MicroPlate Reader using Microlog 4.2 software. Acid production from various sugars was tested as described by Smith et al. (1952). Antibiotic susceptibility was tested by placing antibiotic discs (HiMedia) on Mueller-Hinton agar plates seeded with suspensions of strain $\mathrm{K} 22-20^{\mathrm{T}}$.

Freeze-dried cells for chemotaxonomic analysis were prepared following growth of the strain in shake flasks containing tryptone soya broth (TSB; HiMedia) for 4 days at $28^{\circ} \mathrm{C}$. Whole-cell sugars were determined as described by Staneck \& Roberts (1974). Peptidoglycan structure was determined using hydrolysates of purified cell walls according to Schleifer (1985). Amino acids and peptides were 
separated by two-dimensional ascending TLC as described by Schleifer \& Kandler (1972) with the modification that TLC on cellulose sheets (Merck 5577) was used instead of paper chromatography. Phospholipids and menaquinones were extracted and analysed as described by Minnikin et al. (1984). The glycolic acid content of the bacterial cell wall was determined by the colour reaction method of Uchida et al. (1999). For cellular fatty acid analysis, cells were grown on TSA at $28^{\circ} \mathrm{C}$ for $36 \mathrm{~h}$ and fatty acid methyl ester analysis was performed with the Sherlock Microbial Identification System (MIDI) as described previously (Pandey et al., 2002). DNA-DNA hybridization was performed by the membrane filter method (Tourova \& Antonov, 1987). The genomic DNA G + C content was determined spectrophotometrically (Lambda35; Perkin Elmer) using the thermal denaturation method (Mandel \& Marmur, 1968).

The chromosomal DNA of strain $\mathrm{K} 22-20^{\mathrm{T}}$ was isolated according to Rainey et al. (1996). The 16S rRNA gene was amplified with primers 8-27f ( $5^{\prime}$-AGAGTTTGATCCTGGCTCAG-3') and 1500r ( $5^{\prime}$-AGAAAGGAGGTGATCCAGCCA- $\left.3^{\prime}\right)$. The amplified DNA fragment was separated on $1 \%$ agarose gel, eluted from the gel and purified using a QIAquick gel extraction kit (Qiagen). The purified PCR product was sequenced with four forward and three reverse primers, namely 8-27f, 357f (5'-CTCCTACGGGAGGCAGCAG-3'), 704f (5'-TAGCGGTGAAATGCGTAGA-3'), 1114f (5'-GCAACGAGCGCAACC-3'), 685r (5'-TCTACGCATTTCACCGCTAC-3'), 1110r (5'-GGGTTGCGCTCGTTG-3') and 1500r (Escherichia coli numbering system). The 16S rRNA gene sequence was determined by the dideoxy chain-termination method with the Big-Dye terminator kit using an ABI 310 Genetic Analyzer (Applied Biosystems). The 16S rRNA gene sequence of strain K22- $20^{\mathrm{T}}$ generated in this work (1488 bases) was aligned with 16S rRNA gene sequences of $O$. humiphilum and other members of the family Intrasporangiaceae and suborder Micrococcineae. A sequence similarity search was done using GenBank BLASTN (Altschul et al., 1997). Sequences of closely related taxa were retrieved and aligned using the program CLUSTAL_X (Thompson et al., 1997) and the alignment was corrected manually. For neighbour-joining analysis (Saitou \& Nei, 1987), distances between the sequences were calculated using Kimura's two-parameter model (Kimura, 1980). Bootstrap analysis was performed to assess the confidence limits of the branching (Felsenstein, 1985).

Detailed test reactions are presented in the species description. Based on biochemical characteristics, strain K22-20 ${ }^{\mathrm{T}}$ differed from the closely related species O. humiphilum (Table 1). Most of the chemotaxonomic properties (presented in the species description) were typical of members of the genus Ornithinimicrobium. Cellular fatty acids differed quantitatively between strain $\mathrm{K} 22-20^{\mathrm{T}}$ and the type strain of O. humiphilum (Table 2). To determine the phylogenetic relationships of strain $\mathrm{K} 22-20^{\mathrm{T}}$, the $16 \mathrm{~S}$ rRNA gene sequence (1488 bp) was compared with those of type strains of species of the genera retrieved from GenBank. Results revealed that
Table 1. Differential phenotypic characteristics of strain $\mathrm{K} 22-20^{\top}$ and O. humiphilum MTCC $6406^{\top}$

All data are from the present study. Both strains are Gram-positive, do not produce endospores, are non-acid-fast and do not produce acid from L-arabinose, cellobiose, salicin, D-glucose, D-melibiose, D-lactose, inulin, D-mannose, L-rhamnose or D-xylose. Both strains are positive in the Biolog GP2 MicroPlate tests for dextrin, $\alpha$-Dglucose, maltose, maltotriose, D-mannose, methyl $\alpha$-D-glucoside, D-ribose, sucrose, D-trehalose, D-xylose, acetic acid, pyruvic acid, succinic acid, glycerol, adenosine, 2'-deoxyadenosine, inosine, thymidine, uridine, AMP and TMP; both are negative for $\alpha$ - and $\beta$-cyclodextrin, inulin, Tweens 40 and $80, N$-acetyl-D-glucosamine, $N$-acetyl- $\beta$-D-mannosamine, amygdalin, L-arabinose, L-fucose, Dgalacturonic acid, myo-inositol, $\alpha$-D-lactose, lactulose, D-mannitol, D-melezitose, D-melibiose, methyl $\alpha$-D-galactoside, methyl $\beta$-Dgalactoside, 3-methylglucose, methyl $\beta$-D-glucoside, methyl $\beta$-Dmannoside, L-rhamnose, sedoheptulosan, D-sorbitol, D-tagatose, xylitol, $\alpha$ - and $\gamma$-hydroxybutyric acid, $p$-hydroxyphenylacetic acid, $\alpha$-ketoglutaric acid, lactamide, D-lactic acid methyl ester, L-lactic acid, D- and L-malic acid, succinamic acid, $N$-acetyl-L-glutamic acid, D-alanine, L-alanyl glycine, L-asparagine, L-glutamic acid, glycyl L-glutamic acid, L-pyroglutamic acid, L-serine, putrescine, 2,3-butanediol, D-fructose 6-phosphate, $\alpha$-D-glucose 1-phosphate, D-glucose 6-phosphate and DL- $\alpha$-glycerol phosphate. Both grow in 2 and $4 \% \mathrm{NaCl}$, but not in $8 \% \mathrm{NaCl}$. Neither strain grows at 4 or $55^{\circ} \mathrm{C}$. Both strains are negative for methyl red and VogesProskauer tests, indole, hydrogen sulphide production and oxidase. Both are sensitive to colistin (10 $\mu$ g per disc) and polymyxin $B$ (300 $\mu$ g per disc).

\begin{tabular}{|lcc|}
\hline Characteristic & K22-20 & MTCC $\mathbf{~ 6 4 0 6}^{\mathbf{T}}$ \\
\hline Colony colour & BY & LY \\
Acid production from: & & \\
D-Fructose & + & - \\
D-Raffinose & + & - \\
Trehalose & + & - \\
Maltose & + & - \\
Sucrose & + & - \\
Growth at $42{ }^{\circ} \mathrm{C}$ & - & + \\
Growth at pH 9.0 & + & - \\
Growth on 7\% NaCl & + & - \\
Nitrate reduction & + & - \\
Utilization of: & & - \\
Acetate & + & - \\
Citrate & + & - \\
Benzoate & + & - \\
Utilization as sole carbon source $\dagger$ & & - \\
Glycogen & + & - \\
Mannan & + & - \\
D-Arabitol & + & - \\
Arbutin & + & - \\
D-Cellobiose & + & - \\
D-Fructose & + & - \\
D-Galactose & + & - \\
Gentiobiose & + & - \\
D-Gluconic acid & + & - \\
Palatinose & + & - \\
\hline
\end{tabular}


Table 1. cont.

\begin{tabular}{|lcc|}
\hline Characteristic & K22-20 & MTCC $^{\mathbf{T}} \mathbf{6 0 6}^{\mathbf{T}}$ \\
\hline D-Psicose & + & - \\
D-Raffinose & + & - \\
Salicin & + & - \\
Stachyose & + & - \\
Turanose & + & - \\
$\beta$-Hydroxybutyric acid & + & - \\
$\alpha$-Ketovaleric acid & - & + \\
Succinic acid monomethyl ester & - & + \\
Propionic acid & - & + \\
L-Alaninamide & + & - \\
Susceptibility to: & & - \\
Lincomycin $(2 \mu \mathrm{g}$ per disc $)$ & + & - \\
Triple sulphas $(300 \mu \mathrm{g}$ per disc $)$ & + & \\
\hline
\end{tabular}

${ }^{\star}$ BF, Buff yellow; LY, lemon yellow.

$\nmid$ Using Biolog GP2 MicroPlates.

strain $\mathrm{K} 22-20^{\mathrm{T}}$ is a member of the suborder Micrococcineae (Stackebrandt et al., 1997) (Fig. 1). Strain K22-20 ${ }^{\mathrm{T}}$ showed $97 \cdot 7 \% 16 \mathrm{~S}$ rRNA gene sequence similarity to O. humiphilum HKI $0124^{\mathrm{T}}$ and low similarity values $(95 \cdot 0-89 \cdot 0 \%)$ to members of the genera Ornithinicoccus, Demetria, Curtobacterium, Terracoccus, Promicromonospora, Beutenbergia, Kocuria, Dermatophilus, Sanguibacter, Cellulomonas, Stomatococcus, Arthrobacter, Bogoriella, Brachybacterium, Nesterenkonia, Rarobacter, Dermabacter, Microbacterium and Jonesia.

To determine the genotypic relatedness between strain $\mathrm{K} 22-20^{\mathrm{T}}$ and O. humiphilum MTCC $6406^{\mathrm{T}}$, DNA-DNA hybridization studies were performed. The DNA-DNA
Table 2. Fatty acid compositions of strain $\mathrm{K} 22-20^{\top}$ and $\mathrm{O}$. humiphilum MTCC $6406^{\top}$

Values are percentages of total fatty acids, determined in the present study. -, Not detected.

\begin{tabular}{|c|c|c|}
\hline Fatty acid & $\mathrm{K} 22-20^{\mathrm{T}}$ & MTCC $6406^{\mathrm{T}}$ \\
\hline $\mathrm{C}_{15: 0}$ & $1 \cdot 18$ & $1 \cdot 2$ \\
\hline$C_{16: 0}$ & $2 \cdot 98$ & $16 \cdot 93$ \\
\hline $\mathrm{C}_{17: 0}$ & $2 \cdot 57$ & $4 \cdot 95$ \\
\hline iso- $\mathrm{C}_{14: 0}$ & $0 \cdot 66$ & - \\
\hline iso- $\mathrm{C}_{15: 0}$ & $19 \cdot 42$ & $21 \cdot 17$ \\
\hline anteiso- $\mathrm{C}_{15: 0}$ & $6 \cdot 52$ & $1 \cdot 72$ \\
\hline iso- $\mathrm{C}_{16: 0}$ & $18 \cdot 60$ & $19 \cdot 99$ \\
\hline iso- $\mathrm{C}_{17: 0}$ & $12 \cdot 40$ & $7 \cdot 73$ \\
\hline iso- $\mathrm{C}_{17: 1} \omega 9 c$ & $20 \cdot 39$ & $13 \cdot 68$ \\
\hline anteiso- $\mathrm{C}_{17: 0}$ & $7 \cdot 92$ & $3 \cdot 1$ \\
\hline anteiso- $\mathrm{C}_{17: 1} \omega 9 c$ & $0 \cdot 83$ & - \\
\hline $\mathrm{C}_{17: 1} \omega 8 c$ & $2 \cdot 96$ & $6 \cdot 01$ \\
\hline $\mathrm{C}_{17: 0}$ 10-methyl & $1 \cdot 26$ & - \\
\hline Summed feature $3^{*}$ & $0 \cdot 79$ & $7 \cdot 83$ \\
\hline
\end{tabular}

${ }^{*}$ Summed feature 3 represents iso- $\mathrm{C}_{16: 1} \omega 7 c$ and/or $\mathrm{C}_{15: 0}$ iso $2-\mathrm{OH}$, which could not be separated by GC with the MIDI Sherlock Identification system.

hybridization value was $64 \cdot 5 \%$, which is below the $70 \%$ cut-off value recommended for the delineation of bacterial species (Wayne et al., 1987). The DNA G + C content of strain $\mathrm{K} 22-20^{\mathrm{T}}$ is $71 \mathrm{~mol} \%$. This polyphasic study revealed that strain $\mathrm{K} 22-20^{\mathrm{T}}$ could be clearly distinguished from the type species of the genus Ornithinimicrobium. Based on the above data, it is proposed that strain $\mathrm{K} 22-20^{\mathrm{T}}$ represents a novel species of the genus Ornithinimicrobium, Ornithinimicrobium kibberense sp. nov.

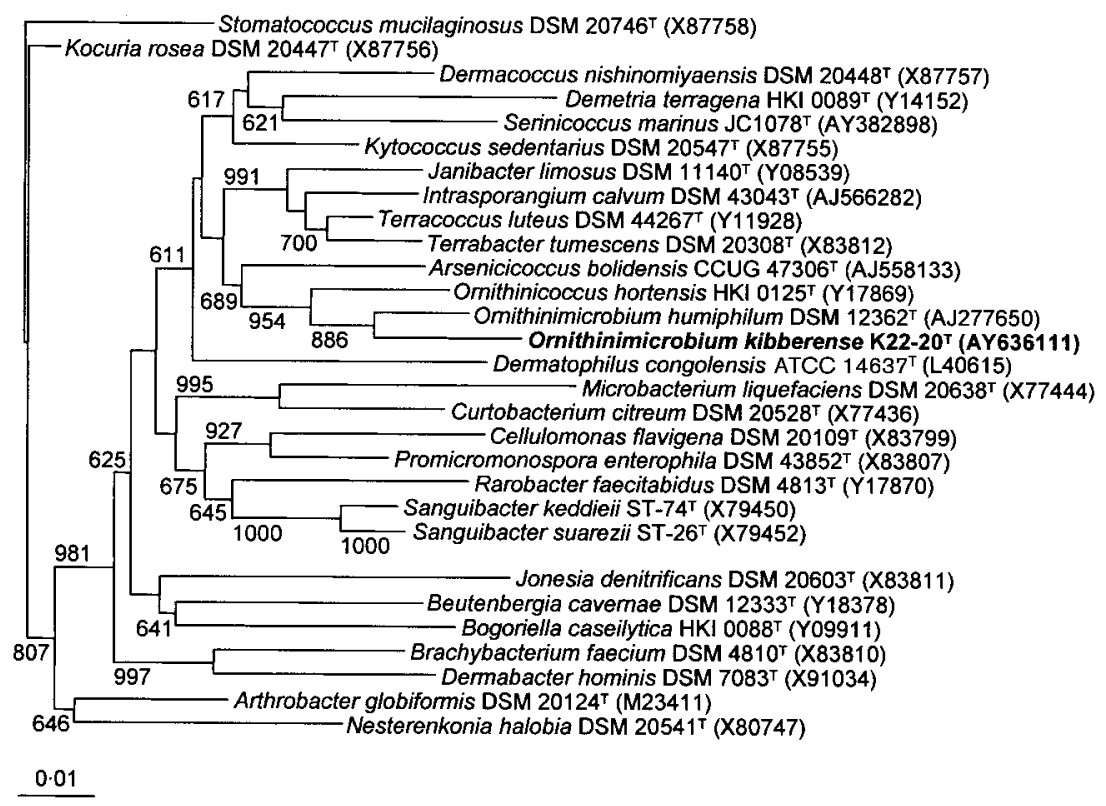

Fig. 1. Neighbour-joining tree based on $16 \mathrm{~S}$ rRNA gene sequences (1488 bases) showing the phylogenetic relationship between strain $\mathrm{K} 22-20^{\top}$ and Ornithinimicrobium humiphilum and other members of the family Intrasporangiaceae and families of the suborder Micrococcineae. Bootstrap values greater than 500 (1000 replications) are given at the nodes. Bar, $1 \%$ sequence variation. 


\section{Description of Ornithinimicrobium kibberense sp. nov.}

Ornithinimicrobium kibberense (kib.be.ren'se. N.L. neut. adj. kibberense pertaining to Kibber, a village in the Indian Himalayas, where the type strain was isolated).

Colonies on TSA are buff-yellow-pigmented and about 1-3 mm in diameter, circular, smooth, glistening, opaque and convex with an entire margin. Catalase-positive and oxidase-negative. Grows at $20-37^{\circ} \mathrm{C}$; optimum growth temperature is $28^{\circ} \mathrm{C}$ and no growth occurs at $42{ }^{\circ} \mathrm{C}$. $\mathrm{NaCl}$ is tolerated up to $7 \%$. Positive for hydrolysis of starch and nitrate reduction and variable for casein hydrolysis. Negative for indole, hydrogen sulphide production and methyl red and Voges-Proskauer tests. Acid is produced from D-fructose, D-galactose, raffinose, sucrose, trehalose and D-maltose, but not from salicin, D-glucose, D-melibiose, L-arabinose, D-mannose, inulin, D-lactose, L-rhamnose, D-xylose, cellobiose or D-mannitol. Utilization of various substrates as sole carbon sources and sensitivity to antibiotics are given in Table 1. The diagnostic cell wall amino acid is L-ornithine and the interpeptide bridge consists of L-Orn, L-Ala, Gly and D-Asp. Whole-cell sugars are glucose, arabinose and xylose. The acyl type is acetyl. Major fatty acids are iso- $\mathrm{C}_{17: 1} \omega 9 c(20 \cdot 39 \%)$, iso- $\mathrm{C}_{15: 0}(19 \cdot 42 \%)$, iso$\mathrm{C}_{16: 0}(18 \cdot 60 \%)$ and iso- $\mathrm{C}_{17: 0}(12 \cdot 40 \%)$. The phospholipid is of type $\mathrm{V}$, with phosphatidylinositol, phosphatidylglycerol, diphosphatidylglycerol and unknown glucosaminecontaining phospholipids. The major menaquinone is MK-8 $\left(\mathrm{H}_{4}\right)$. Mycolic acids are absent. The DNA G+C content of the type strain is $71 \mathrm{~mol} \%$.

The type strain is $\mathrm{K} 22-20^{\mathrm{T}} \quad\left(=\mathrm{MTCC} \quad 6545^{\mathrm{T}}=\mathrm{DSM}\right.$ $17687^{\mathrm{T}}=\mathrm{JCM} 12763^{\mathrm{T}}$ ), isolated from soil, $45 \mathrm{~cm}$ below an ice glacier, $4200 \mathrm{~m}$ above sea level, in Kibber village of the Spiti valley, Himachal Pradesh, India.

\section{Acknowledgements}

We thank Dr J. P. Euzéby, Ecole Nationale Veterinaire, France, for his suggestion on Latin nomenclature for the novel species. We would like to thank Mr Malkit Singh for his excellent technical assistance. P. S. is the recipient of the CSIR research fellowship. Financial assistance from the CSIR and DBT, Government of India is duly acknowledged. This is IMTECH communication number 50/2005.

\section{References}

Altschul, S. F., Madden, T. L., Schaffer, A. A., Zhang, J., Zhang, Z., Miller, W. \& Lipman, D. J. (1997). Gapped BLAST and PSI-BLAST: a new generation of protein database search programs. Nucleic Acids Res 25, 3389-3402.

Bergey, D. H., Harrison, F. C., Breed, R. S., Hammer, B. W. \& Huntoon, F. M. (1923). Bergey's Manual of Determinative Bacteriology. Baltimore: Williams \& Wilkins.

Claus, D. \& Berkeley, R. C. W. (1986). Genus Bacillus Cohn 1872, $174^{\mathrm{AL}}$. In Bergey's Manual of Systematic Bacteriology, vol. 2, pp. 1105-1139. Edited by P. H. A. Sneath, N. S. Mair, M. E. Sharpe \& J. G. Holt. Baltimore: Williams \& Wilkins.
Collins, M. D., Routh, J., Saraswathy, A., Lawson, P. A., Schumann, P., Welinder-Olsson, C. \& Falsen, E. (2004). Arsenicicoccus bolidensis gen. nov., sp. nov., a novel actinomycete isolated from contaminated lake sediment. Int J Syst Evol Microbiol 54, 605-608.

Cowan, S. T. \& Steel, K. J. (1965). Manual for the Identification of Medical Bacteria. London: Cambridge University Press.

Felsenstein, J. (1985). Confidence limits on phylogenies: an approach using the bootstrap. Evolution 39, 783-791.

Groth, I., Schumann, P., Martin, K., Schuetze, B., Augsten, K., Kramer, I. \& Stackebrandt, E. (1999). Ornithinicoccus hortensis gen. nov., sp. nov., a soil actinomycete which contains L-ornithine. Int J Syst Bacteriol 49, 1717-1724.

Groth, I., Schumann, P., Weiss, N., Schuetze, B., Augsten, K. \& Stackebrandt, E. (2001). Ornithinimicrobium humiphilum gen. nov., sp. nov., a soil actinomycete with L-ornithine in the peptidoglycan. Int J Syst Evol Microbiol 51, 81-87.

Kimura, M. (1980). A simple method for estimating evolutionary rates of base substitutions through comparative studies of nucleotide sequences. J Mol Evol 16, 111-120.

Mandel, M. \& Marmur, J. (1968). Use of ultraviolet absorbancetemperature profile for determining the guanine plus cytosine content of DNA. Methods Enzymol 12B, 195-206.

Minnikin, D. E., O'Donnell, A. G., Goodfellow, M., Alderson, G., Athalye, M., Schaal, K. \& Parlett, J. H. (1984). An integrated procedure for the extraction of bacterial isoprenoid quinones and polar lipids. J Microbiol Methods 2, 233-241.

Murray, R. G. E., Doetsch, R. N. \& Robinow, C. F. (1994). Determinative and cytological light microscopy. In Methods for General and Molecular Bacteriology, pp. 21-41. Edited by P. Gerhardt, R. G. E. Murray, W. A. Wood \& N. R. Krieg. Washington, DC: American Society for Microbiology.

Orla-Jensen, S. (1919). The Lactic Acid Bacteria. Copenhagen: Høst. Pandey, K. K., Mayilraj, S. \& Chakrabarti, T. (2002). Pseudomonas indica sp. nov., a novel butane-utilizing species. Int J Syst Evol Microbiol 52, 1559-1567.

Rainey, F. A., Ward-Rainey, N., Kroppenstedt, R. M. \& Stackebrandt, E. (1996). The genus Nocardiopsis represents a phylogenetically coherent taxon and a distinct actinomycete lineage: proposal of Nocardiopsaceae fam. nov. Int J Syst Bacteriol 46, 1088-1092.

Reddy, G. S. N., Prakash, J. S. S., Prabahar, V., Matsumoto, G. I., Stackebrandt, E. \& Shivaji, S. (2003). Kocuria polaris sp. nov., an orange-pigmented psychrophilic bacterium isolated from an Antarctic cyanobacterial mat sample. Int J Syst Evol Microbiol 53, 183-187.

Saitou, N. \& Nei, M. (1987). The neighbor-joining method: a new method for reconstructing phylogenetic trees. Mol Biol Evol 4, 406-425.

Schleifer, K. H. (1985). Analysis of the chemical composition and primary structure of murein. Methods Microbiol 18, 123-156.

Schleifer, K. H. \& Kandler, O. (1972). Peptidoglycan types of bacterial cell walls and their taxonomic implications. Bacteriol Rev 36, 407-477.

Sheridan, P. P., Loveland-Curtze, J., Miteva, I. V. \& Brenchley, E. J. (2003). Rhodoglobus vestalii gen. nov., sp. nov., a novel psychrophilic organism isolated from an Antarctic Dry Valley lake. Int J Syst Evol Microbiol 53, 985-994.

Smibert, R. M. \& Krieg, N. R. (1994). Phenotypic characterization. In Methods for General and Molecular Bacteriology, pp. 607-654. Edited by P. Gerhardt, R. G. E. Murray, W. A. Wood \& N. R. Krieg. Washington, DC: American Society for Microbiology.

Smith, N. R., Gordon, R. E. \& Clark, F. E. (1952). Aerobic sporeforming bacteria. US Department of Agriculture Agricultural Monograph no. 16. Washington, DC: US Department of Agriculture. 
Stackebrandt, E., Rainey, F. A. \& Ward-Rainey, N. (1997). Proposal for a new hierarchic classification system, Actinobacteria classis nov. Int J Syst Bacteriol 47, 479-491.

Staneck, J. L. \& Roberts, G. D. (1974). Simplified approach to identification of aerobic actinomycetes by thin-layer chromatography. Appl Microbiol 28, 226-231.

Takeuchi, M. \& Hatano, K. (1998). Union of the genera Microbacterium Orla-Jensen and Aureobacterium Collins et al. in a redefined genus Microbacterium. Int J Syst Bacteriol 48, 739-747.

Thompson, J. D., Gibson, T. J., Plewniak, F., Jeanmougin, F. \& Higgins, D. G. (1997). The CLUSTAL_X windows interface: flexible strategies for multiple sequence alignment aided by quality analysis tools. Nucleic Acids Res 25, 4876-4882.

Tourova, T. P. \& Antonov, A. S. (1987). Identification of microorganisms by rapid DNA-DNA hybridization. Methods Microbiol 19, 333-355.

Uchida, K., Kudo, T., Suzuki, K. I. \& Nakase, T. (1999). A new rapid method of glycolate test by diethyl ether extraction, which is applicable to a small amount of bacterial cells of less than one milligram. J Gen Appl Microbiol 45, 49-56.
Von Wintzingerode, F., Gobel, U. B., Siddiqui, R. A., Rosick, U., Schumann, P., Fruhling, A., Rohde, M., Pukall, R. \& Stackebrandt, E. (2001). Salana multivorans gen. nov., sp. nov., a novel actinobacterium isolated from an anaerobic bioreactor and capable of selenate reduction. Int J Syst Evol Microbiol 51, 1653-1661.

Wayne, L. G., Brenner, D. J., Colwell, R. R. \& 9 other authors (1987). International Committee on Systematic Bacteriology. Report of the ad hoc committee on reconciliation of approaches to bacterial systematics. Int J Syst Bacteriol 37, 463-464.

Yamada, K. \& Komagata, K. (1972). Taxonomic studies on coryneform bacteria. V. Classification of coryneform bacteria. J Gen Appl Microbiol 18, 417-431.

Yamamoto, N., Sato, S., Saito, K., Hasuo, T., Tadenuma, M., Suzuki, K., Tamaoka, J. \& Komagata, K. (1988). Rarobacter faecitabidus gen. nov., sp. nov., a yeast-lysing coryneform bacterium. Int J Syst Bacteriol 38, 7-11.

Yi, H., Schumann, P., Sohn, K. \& Chun, J. (2004). Serinicoccus marinus gen. nov., sp. nov., a novel actinomycete with L-ornithine and L-serine in the peptidoglycan. Int J Syst Evol Microbiol 54, $1585-1589$. 